\title{
Influence of Debris on Water Intake Gratings in Small Hydroelectric Plants: An Experimental Study on Hydraulic Parameters
}

\author{
Natalia Walczak ${ }^{1, *}$, Zbigniew Walczak ${ }^{2}$ (D) and Jakub Nieć ${ }^{1}$ (D) \\ 1 Department of Hydraulic and Sanitary Engineering, Poznan University of Life Sciences, \\ 60-637 Poznań, Poland; jakub.niec@up.poznan.pl \\ 2 Department of Construction and Geoengineering, Poznan University of Life Sciences, \\ 60-637 Poznań, Poland; zbw@up.poznan.pl \\ * Correspondence: nwalczak@up.poznan.pl; Tel.: +48-061-846-6584
}

Citation: Walczak, N.; Walczak, Z.; Nieć, J. Influence of Debris on Water Intake Gratings in Small Hydroelectric Plants: An Experimental Study on Hydraulic Parameters. Energies 2021, 14, 3248. https://doi.org/10.3390/en14113248

Academic Editor: Chirag Trivedi

Received: 25 April 2021

Accepted: 31 May 2021

Published: 2 June 2021

Publisher's Note: MDPI stays neutral with regard to jurisdictional claims in published maps and institutional affiliations.

Copyright: (c) 2021 by the authors. Licensee MDPI, Basel, Switzerland. This article is an open access article distributed under the terms and conditions of the Creative Commons Attribution (CC BY) license (https:// creativecommons.org/licenses/by/ $4.0 /)$.

\begin{abstract}
Deposition of debris on the screens of hydroelectric power plants translates into measurable economic losses. Occurring plant debris, although it is an organic material, is characterised by different forms and structure. It is often leaves, branches, and grasses in lowland areas, while in mountainous regions, broken boughs and trees can be expected. On the trash racks of power plants, debris may be deposited in different forms, shapes, and places. This work aims to determine the impact of the degree of submergence of debris on the values of the force acting on the racks. This paper analyzes the influence of the rectangular shape of the debris deposited on the trash racks and its degree of submergence and weight on the obtained values of the force acting on the racks as a result of water pressure, which directly affects the hydraulic losses and productivity of hydroelectric power plants. Our research confirms the negative influence of the deposited plant debris on the value of forces recorded on the gratings. The increase in the recorded force, and thus the resistance on the grating, is obviously dependent on the degree of obstruction of the debris by the grating obtained by changing the degree of debris immersion and its weight. In the case of changing the degree of submergence, the increase in force recorded on the gratings varied during the experiment from about $25 \%$ recorded for the fully submerged debris compared to that of the partially submerged debris for the mass of $100 \mathrm{~g}$; in comparison, an increase of about $31 \%$ was recorded for that of the mass of $200 \mathrm{~g}$. However, comparing the values of the forces recorded on the obstructed grids to that of the forces recorded on the clean grids, the increase ranged from about $15-53 \%$.
\end{abstract}

Keywords: SHP; hydropower; plant debris; trash racks; head losses

\section{Introduction}

White carbon (or water) was traditionally used for energy generation. This involves the construction of a hydroelectric power plant, for which constraints related to terrain, hydrological and geological conditions, and economics are important factors related to energy production. It is important to identify the hydrological regime's characteristics at the investment project stage, especially in terms of outflow stability. This is due to the variability of climatic conditions and the significant human impact on the water cycle. Notable aspects include the seasonality of river outflow, availability and size of water resources, sustainability, and predictability. Hydropower is based on using the potential of water and converting it into mechanical energy through water turbines and then into electricity through hydro generators. Hydropower is based on water use with high flow rates and water levels at the upper and lower positions.

The development of hydropower is influenced by natural, social, and economic factors, and the hydropower potential of various regions (financial profitability and technical feasibility) and climate change [1-3]. 
The literature dealt extensively with aspects such as the impact of hydropower plants on the environment, which was evaluated by assessing their impact on aquatic organisms and the functionality of water-related ecosystems [4-9]. Additionally, many authors [10-13] analyzed hydrological conditions below damming structures along with transport and the composition of bottom sediments. The studies also considered accumulation and erosion processes [14-17], hydromorphological conditions [18-22], water quality [23-26], and socioeconomic issues [27-32].

The correct design of hydrotechnical structures should meet the basic principles of sustainable development, i.e., investments should be designed and made in technical terms, under applicable standards and regulations, and provide certain economic benefits and guarantee the absence of environmental hazards. The idea of sustainable development is an overarching objective of the European Union and assumes an increase in the level and quality of life by promoting economic, social, and environmental development. Global resources of fossil fuels, solid, liquid, or gaseous, gradually became depleted, which correlates with increased prices. On the one hand, the desire to reduce greenhouse gas emissions, and on the other hand, search for new sources of energy alternative to fossil fuels is making the use of renewable energy sources increasingly common. Therefore, hydropower is recognised as very important in numerous countries [33]. They are particularly considering that it reduces pollution and greenhouse gas emissions and may positively impact entire populations' quality of life [34]. However, it also has some negative environmental effects, generally associated with fauna and flora [35]. Valero [36] indicated that the most significant negative impact of Small Hydroelectric Power (SHP) on water quality and habitat conditions of riparian flora could be observed during the construction of a facility and up to two years after its completion. After this period, both the temperature and the oxygen content dissolved in water reach the values necessary for the normal development of life in water. The $\mathrm{pH}$ also stabilizes near acceptable limits. Small Hydropower Plants also affect variables such as the values of flow rate and water depth, which directly translates into their environmental impact [37-40].

Each hydrotechnical structure equipped with a pipe with grates can change the flow characteristics above the station by increasing the water table's height due to limiting the volume of water flowing into the culvert. This effect may be exacerbated in the presence of contaminants if trapped at the inlet [41]. This will also apply to icing phenomena on gratings [42-44]. Consequently, pipe-especially those prone to clogging - can significantly increase the water runoff potential and the risk of severe flooding. This phenomenon was studied by Blanc et al. [45] in a laboratory experiment using a grating made of artificial elements as a detail that blocks the free flow. An analysis based on a large number of trials $(105,000)$ showed that the possibility of blockage of the grating by contaminants increases with increasing the ratio of the length of the flow blocking fragments to the distance between the bars. Besides, it was shown that the grating angle and position have a significant effect on the clogging potential.

It is reasonable to leave vegetation in river valleys, but it is essential to remember that it can contribute to flooding risk. During more significant precipitation events, vegetation debris (branches, boughs) and whole trees located above the catchment area can be picked up and transported in the direction of water runoff, and if retained on hydraulic structures (bridges, culverts), can cause blockages. These pollutants are often trapped by hydraulic structures, causing them to become wholly or partially blocked, reducing their capacity. This conclusion was reached by Jaeger and Lucke [46], who, based on a laboratory study, showed that the mobility of vegetation elements during rainfall events was dependent on several factors, including channel depth and width, size, and accessibility, and vegetation condition. The above mentioned may have significant implications for culvert design and maintenance procedures.

The role of floodplains is to contain, slow down, and reduce the flood wave. During floods, shrubby vegetation of floodplains "traps" most organic and inorganic components (called debris) accumulated in the area and may hinder the free flow of water during the 
next flood. Debris also transported during regular river flows and may be deposited on the vegetation growing onshore areas, partially submerged, sometimes significantly affecting the flow. Periodically or at high water in a river, it may be activated and transported further, depositing on subsequent natural or artificial barriers, e.g., grates on hydropower plants.

Vegetation in river valleys can serve many functions, e.g., it retains debris flow and becomes a bioengineering tool in regulating water flow, provided it is used properly. Lack of complete river morphological studies and vegetation inventories can sometimes cause environmental hazards [47]. Michelini et al. [48] determined the interaction between debris flows and forest vegetation for two alpine areas based on field studies. From their point of view, forested areas can have a protective function by impeding the movement of debris flows and preventing rapid deposition. The study's main results confirmed the forest's ability to dissipate flow energy evenly while taking into account the high species diversity of debris deposits. A similar study was conducted by Shen et al. [49], who analyzed vegetation's role in mitigating slope erosion caused by debris flow.

In rivers with natural water flow, transport of organic material is encountered, the composition of which depends on the conditions of the watercourse. In the mountains, woody debris, which consists of whole trees, branches, or shrubs, is most common. Awareness of the threats posed by large trees is increasing, and they can reduce the stability of hydraulic structures by other subjection of floodwaters.

Gasser et al. [50] researched the role of vegetation in the river and sloped morphological processes. They created a proprietary model based on research in the Swiss Prelps to locate areas where vegetation (especially trees) can increase slope and bank stability.

Lowland rivers will be dominated by organic debris with fine vegetation elements, such as branches, stems, and leaves. Fine plant debris plays an important role in river flow analyses.

The fine plant debris composition depends on the river valley's development, phenological changes, and sudden changes in hydrometeorological phenomena. The immediate ecological status of rivers informs about the quantity and quality of the debris. For different water levels, debris parameters change. At low and medium flows, mainly leaves, twigs, fragments of macroliths, i.e., fine organic materials, are transported [51]. When a surge occurs, blades of dry grasses, tree trunks located on slopes, and branches are transported. The matter accumulated over the years is activated during flood surges.

One of the main problems faced by flow structures is the material that can accumulate in openings and culverts and threaten the stability of structures such as bridges $[52,53]$. Research on this issue was carried out by [54], among others for whom grates are one of the main control measures used to contain debris and stop it from entering open structures, which can cause undesirable effects.

Debris accumulating in open channels can complicate the operation of engineering structures. This conclusion was reached by [55], who developed a system for simulating floating objects in open channels (ice, debris) resulting from combining a two-dimensional, mean-depth flow model with a discrete element model. The study's objective was to present a complex interaction of barges, ice floes, and floating debris with structures on bridges, inlets, locks, and dams under the influence of the river current. The study results were verified by modeling debris transitions in the Harlan Diversion Tunnel and at the locks and Greenup Dam. The developed model can be useful in evaluating debris accumulation and remediation alternatives. The combined model can estimate forces on hydraulic structures and the hydraulic influence of various structural components.

Since accurate numerical modeling of the debris accumulation process is still challenging given the nonuniformity of its accumulation and the interaction between different sized material, small-scale modeling is one of the main tools to study debris structures. Such research was addressed by [56], among others, who conducted a systematic study of debris accumulation in a laboratory environment on a debris track. The results of their research indicate a significant influence of the Froude number on the flow that initiates the debris accumulation process. Geometrical parameters and their diversity (logs, branches) 
have only minor influence on the increase of flow depth and can be neglected. A similar study under laboratory conditions was conducted by [57] using the debris of different geometric sizes, taking into account the fine fractions (leaves and branches). The conclusions of this study contributed to a better understanding of the process of fine organic matter accumulations. The analyses found that backwater rise mainly depends on the approach flow Froude number, compactness of large wood accumulations, and percentage of fine organic material. The authors developed an equation to calculate backwater rise due to large wood accumulations, contributing to estimating the potential hazard assessment of river infrastructures for flood events.

Considering the increasing frequency and magnitude of flood flows, the development of riparian forests and the restoration of streams [58,59], uncontrolled transport of debris can be a major problem in maintaining the proper operation, hydroelectric facilities in the future. One of the main countermeasures to prevent these problems is the retention of debris using grids.

Considering the above, it seems important to determine the influence of plants debris that accumulate in the water-inlet grids of hydroelectric turbines on the size of flow resistance. Therefore, the influence of the weight and degree of immersion of the plant debris accumulated on the grids on the magnitude of the water pressure force acting on the grids was analyzed.

\section{Materials and Methods}

Laboratory studies investigated the effect of shape, weight, and degree of submergence of plant debris on the obtained force values recorded using a strain gauge bridge.

The tests were carried out in a rectangular glazed hydraulic trough $12 \mathrm{~m}$ long, $0.48 \mathrm{~m}$ wide and $0.90 \mathrm{~m}$ high at J.B. Lewandowski Water Laboratory at the Department of Hydraulic and Sanitary Engineering of the University of Life Sciences in Poznań (as illustrated in Figure 1). The filling of the flume was adjusted by a flap mounted at the end of the hydraulic flume, and the flow rate was measured using Siemens Sitrans FM Magflo MAG 1100 electromagnetic flow meter and MAG 5000 measuring transducer, whose range of measured flows was adjusted to the maximum flow rate $\left(0.1 \mathrm{~m}^{3} \mathrm{~s}^{-1}\right)$, and the measurement accuracy is $0.5 \%$ of the flow rate. The drag force was measured using a dynamometric platform to determine the water pressure values expressed in Newtons. The dynamometer platform was located at a distance of $9.0 \mathrm{~m}$ from the water inlet to the flume. The dynamometric platform was connected to a tensometric force sensor type CL-17 pm, ZEPWN Manufacturing, operating the maximum to $50 \mathrm{~N}$ range with a sensitivity of $1 \mathrm{mVIV}$. The research arrangement serves to transfer the force acting on installed trash racks, regardless of where it is applied. The force values were recorded for $2 \mathrm{~min}$ with a frequency of $0.02 \mathrm{~s}$ (6000 samples). The measured values were recorded using RECORDER (software from ZEPWN Manufacturing).

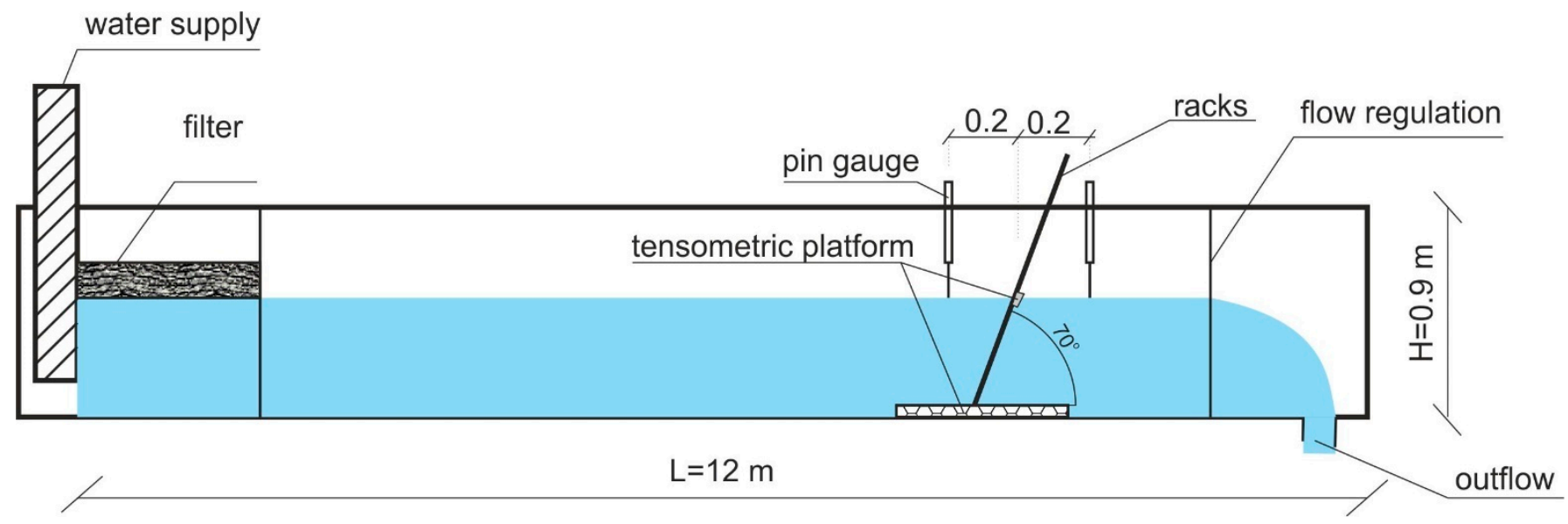

Figure 1. Scheme of laboratory test. 
Data were recorded using a USB-26 type measuring system (ZEPWN Manufacturing). It was written to a log file using the "Recorder" software in both spreadsheet and graph form after transfer to a computer.

The choice of grating shape is also necessary to the studies analyzed. During our research, rectangular racks with $10 \mathrm{~mm}$ bar spacing were used. The flat bar, which influences the values of hydraulic losses causing them to increase, also affects the efficiency of capturing fine plant debris represented by grasses and branches. During cleaning, significant forces are exerted on the gratings, especially during removing plant debris wedged between the bars. This phenomenon can adversely affect and damage the grating structure. Also, depending on the hydropower plant's location, the grates in the inlet channels are exposed to different types of debris.

In fluid mechanics, the drag force's correct determination is very important. The Stokes formula expresses the force for the special case of a rigid spherical particle moving very slowly in a viscous fluid. However, in the vast majority of cases, this formula's use is impossible due to the shape of the particles under analysis. Therefore, a different relation for the drag force is often used [60]:

$$
F=\frac{C_{W} \rho v_{a v}^{2} A_{p}}{2},
$$

where:

F-drag force, [N];

$C_{W}$-drag coefficient, [-];

$A_{p}$ - projection field of the flowed element on the surface perpendicular to the flow direction, $\left[\mathrm{m}^{2}\right]$;

$\rho$-water density $\left[\mathrm{kg} \cdot \mathrm{m}^{-3}\right]$, in the calculations, it was assumed $\rho \approx 1000\left[\mathrm{~kg} \cdot \mathrm{m}^{-3}\right]$ in $10^{\circ} \mathrm{C}$. $v_{a v}$-average free water flow velocity for a given flow rate, determined from the continuity equation $\left[\mathrm{m} \cdot \mathrm{s}^{-1}\right]$,

$$
v_{a v}=\frac{Q}{A} .
$$

where:

$Q$ - the volumetric flow rate $\left[\mathrm{m} \cdot \mathrm{s}^{-1}\right]$;

$A$ - the cross sectional area of flow $\left[\mathrm{m}^{2}\right]$.

This formula is semiempirical, and is sometimes called Newton's law. Knowing the values of the acting forces from the measurements by transforming Equation (1), the drag coefficient can be estimated as follows:

$$
C_{W}=\frac{2 F_{p}}{\rho v_{a v}^{2} A_{p}},
$$

where:

$F_{p}$ - the value of the measured force, [N].

The following parameters were recorded during laboratory tests:

- $\quad$ water depths upstream and downstream of the grids;

- average flow depth;

- $\quad$ average flow velocity;

- $\quad$ forces acting on the grids

measured at the same distance equal $20 \mathrm{~cm}$ from the grid upstream and downstream using pin gauges.

The mean values of the measured forces $F_{p i}$ for each scenario (100 and $200 \mathrm{~g}$ and fullyhalf-submerged debris) were compared to that of the mean $F_{p}$ force measured on clean grids $\left(F_{p i} / F_{p}\right)$ to estimate the increase in force values recorded on the grids due to debris accumulation. The increase in recorded forces with change in the degree of submergence of the debris was also compared. As a basis value, the average force value for the half- 
submerged debris was taken for both 100 and $200 \mathrm{~g}$ of debris. The percentage increase in forces for fully submerged debris was estimated relative to the respective base values.

The blockage ratio $B$ is calculated using the following expression:

$$
B=\frac{A_{d}+A_{t}}{A_{p}},
$$

where:

$A_{d}$-the wetted area of the debris, calculated as the area of the rectangle formed by the debris accumulated on the grids, $\left[\mathrm{m}^{2}\right]$;

$A_{t}$ - the wetted area of the trash rack, calculated by multiplying the average depth, bar thickness, and number of bars of the grating, $\left[\mathrm{m}^{2}\right]$.

In all the experiments and flow rates, the predefined tailgate approach flow depth $h$ of $60-73 \mathrm{~cm}$. Given the approach flow conditions, discharge $\mathrm{Q}=0.011-0.013 \mathrm{~m}^{3} \cdot \mathrm{s}^{-1}$ resulted in the approach flow Froude numbers $F_{\mathrm{o}}=v / \sqrt{(g \cdot h)}$ were equal from 0.013-0.017. These numbers were based on the approach flow velocity $v$, flow depth $h$, and $g$ gravitational accelerating. The corresponding Reynolds number varied from 22,061-22,743 based on the approach flow velocity, flow depth, and kinematic viscosity. Froude number was determined to specify the type of hydraulic flow and to compare with that of other surveys. Reynolds number was indicated as a universal, dimensionless parameter that determines the water flow regime through an obstacle represented by grids.

The study was initiated each time after the hydraulic channel's flow and water levels had stabilised. The debris weight in the first cycle of testing was $100 \mathrm{~g}$, and the inclination of the gratings (flat bars) was constant and equal to an angle of $70^{\circ}$ concerning the water level. The force measurements were carried out at two water table configuration: for the debris fully submerged (as illustrated in Figure 2a) and half-submerged (as illustrated in Figure 2b), designated at R1/1 100 and R1/2 100, respectively. Then, the tests were repeated for the debris with a weight of $200 \mathrm{~g}$, set at R1/1 200 and R1/2 200, respectively.
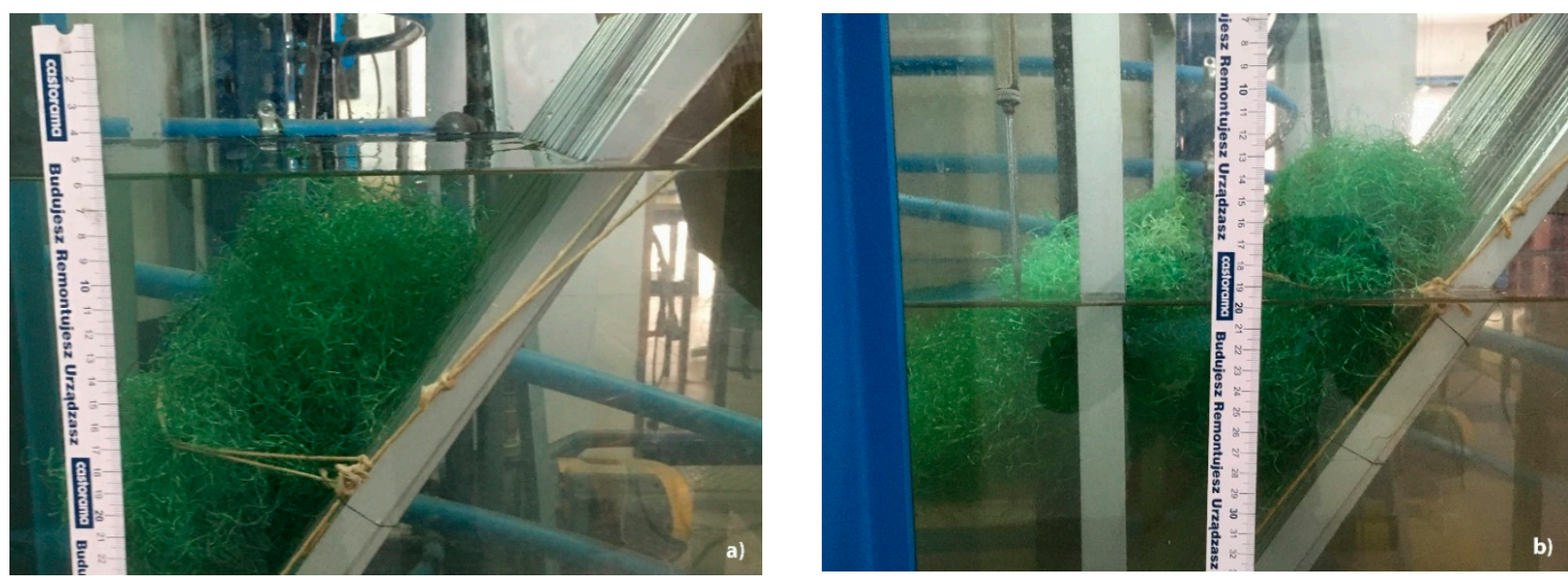

Figure 2. Rectangular form of plant debris found on SHP grids: (a) fully submerged; (b) half-submerged.

The measured data (series) were additionally subjected to statistical analysis, including basic descriptive statistics (summary statistics) for the degree of debris submergence and different weights. Further studies were performed using nonparametric Mann-WhitneyWilcoxon (MWM test, $U$ test) [61,62] and Kruskal-Wallis tests [61]. The hypothesis system for the Kruskal-Wallis test was assumed as follows:

Hypothesis $\left(\mathbf{H}_{\mathbf{0}}\right) \cdot \mu_{R 1 / 1100}=\mu_{R 1 / 2100}=\mu_{R 1 / 1200}=\mu_{R 1 / 2200}$.

Hypothesis $\left(\mathbf{H}_{\mathbf{1}}\right) . \sim H_{0}$ 
As the null hypothesis $H_{0}$, it was assumed that all samples are from a single population. The alternative hypothesis $H_{1}$ is not all samples come from the same populations. Where $\mu_{R 1 / 1100} ; \mu_{R 1 / 2100} ; \mu_{R 1 / 1200 ;} \mu_{R 1 / 2} 200$ are the medians of the study variable in the populations sampled.

A pairwise comparison (Wilcoxon test) was also conducted for each series to determine whether two dependent samples were selected from populations having the same distribution. Each pair was compared using the Mann-Whitney-Wilcoxon test.

The null hypothesis reports that the samples were drawn from the same distribution (Wilcoxon test verifies the equality of medians).

The analyses were performed using the R package and RStudio software [61].

\section{Results and Discussion}

Based on conducted laboratory research, the measured basic parameters' average values are shown in Table 1 . The estimated values of water flow ranged from $0.0118-0.013 \mathrm{~m}^{3} \cdot \mathrm{s}^{-1}$. The rationale for locating debris at the top of the grids was supported by a laboratory study by Xiang et al. [63], which aimed to evaluate the efficiency of plant debris capture by the grids. They found that the velocity profiles changed significantly below the racks above the bottom, and also that the debris moved consistently upward for all replicate runs after some debris was captured by the debris rack. Hence, they accumulated less at the bottom than at the top. The researchers analyzed different grating profile spacing and different slope angles for two flow velocities. Additionally, they analyzed the composition of the debris collected from the grids located at the Tracy Fish Collection Facility in California. Conclusions about the change in debris composition over a year also justify selecting two weights for the study presented here.

Table 1. Hydraulic parameters of water flow.

\begin{tabular}{cccccc}
\hline \multirow{2}{*}{ Parameters } & \multirow{2}{*}{ Units } & \multicolumn{3}{c}{ Rectangle } \\
\cline { 3 - 6 } & & \multicolumn{2}{c}{$\mathbf{1 0 0} \mathbf{g}$} \\
Degree of flooding of the debris & - & $\mathrm{R} 1 / 1$ & $\mathrm{R} 1 / 2$ & $\mathrm{R} 1 / 1$ & $\mathrm{R} 1 / 2$ \\
Water flow Q & $\mathrm{m}^{3} \mathrm{~s}^{-1}$ & 0.0118 & 0.013 & 0.0118 & 0.012 \\
Force F & $\mathrm{N}$ & 0.380 & 0.300 & 0.440 & 0.340 \\
Velocity V & $\mathrm{ms}^{-1}$ & 0.035 & 0.0430 & 0.0350 & 0.042 \\
Froude Number F & - & 0.013 & 0.017 & 0.013 & 0.017 \\
Reynolds Number R & - & 22171 & 23743 & 22061 & 22878 \\
Drag coefficient Cw & - & 16.47 & 17.34 & 19.31 & 20.76 \\
\hline
\end{tabular}

A study on the influence of the shape of the racks on the coefficient of losses on a hydropower plant's gratings was conducted by Lučin, et al. [64]. They found that sharp edges of gratings in cross-sections must be carefully analyzed for economic, operational, and safety reasons.

The study of debris drag forces under laboratory conditions was also addressed by Wallerstein et al. [65] using a hydraulic model based on Abiaca Creek in northern Mississippi. The model was used to examine the geomorphic and hydraulic effects of large woody debris elements attached to a dynamometer to measure drag forces. Channel variability was determined through detailed topographic surveys. The authors observed that the water-resistance force on the elements decreased asymptotically over time as the channel edge zone around the elements eroded due to localized increases in boundary stresses.

Similar studies on the influence of woody elements (branches, logs) left in rivers on increased resistance and affect flow were measured by Hygelund and Manga [66]. They conducted a series of resistance measurements of model woody components under natural conditions. They found that the orientation and position of the log arrangement had no significant effect on the drag coefficient. The log's location played a more considerable role for smaller plant elements because water velocity varied with depth. Resistance is 
also affected by the ratio of log diameter to water depth, and as obscuration increases, resistance increases.

During own measurements, the increased pressure force on the grid (also clean) was determined (as illustrated in Table 2). The least favourable solution for obtained force values is when the plant debris are wholly submerged.

Table 2. Geometric parameters of debris.

\begin{tabular}{cccccc}
\hline Parameters & Units & \multicolumn{2}{c}{$\mathbf{1 0 0} \mathbf{g}$} & \multicolumn{2}{c}{$\mathbf{2 0 0} \mathbf{g}$} \\
\hline Degree of flooding of the debris & - & $\mathrm{R} 1 / 1$ & $\mathrm{R} 1 / 2$ & $\mathrm{R} 1 / 1$ & $\mathrm{R} 1 / 2$ \\
Blockage ratio $B$ & - & 0.294 & 0.245 & 0.294 & 0.246 \\
Increase in force * & $\%$ & +42 & +15 & +53 & +17 \\
Degree of coverage of the active section & $\%$ & 24 & 12 & 24 & 12 \\
\hline
\end{tabular}

${ }^{*}$ In comparison to that of a grating without debris.

The major influence on drag force has blocked ratio $B$, which can be calculated using Equation (4). The introduction of debris into the system caused an increase in recorded force, relative to pure grids, of 1.15-1.5 times for vegetation weighing $100 \mathrm{~g}$ half and fully submerged and for $200 \mathrm{~g}$, respectively. In laboratory studies, Clark et al. [67] evaluated the effect of grating shape on hydraulic losses and indicated that losses increase with increasing velocity and blockage ratio. Studies were conducted for grating models with different cross-sectional shapes and bar thicknesses, depths, and spacings for different velocities. Taking the above into consideration, we found that a change of $B(0.25-0.29)$ parameter depended on water velocity $(0.035-0.043)$ at a different weight.

Gippe et al. [68] came to similar conclusions about the effect of plant debris shape on force values. Based on laboratory experiments, they analyzed debris in lowland rivers and developed a model, based on the momentum principle, of the influence of debris on tide or water table rise. They found that the debris' location and shape have less influence on debris resistance than the orientation relative to the flow and clogging coefficient or the channel's proportion occupied by debris elements. From a hydraulic point of view, more important is the relationship of debris size to the geometric dimensions of the river than the absolute size of the debris. In most lowland rivers, vegetation elements must block more than about $10 \%$ of the flow cross-sectional area to affect flow significantly.

The result of statistical analyses using the Kruskal-Wallis test, where $\chi^{2}=35179, d f=5$, $p$-value $<2.2 \times 10^{-16}$, and a small $p$-value, indicating statistically significant differences between the series.

Multiple pairwise comparisons between groups in the Mann-Whitney-Wilcoxon test are presented in Table 3 and Figure 3 and also confirm the above.

For the rectangular-shaped debris, an increase in the recorded average force was observed (as illustrated in Figure 3), and consequently, an increase in the drag coefficient. For the rectangular shaped debris and mass of $100 \mathrm{~g}$, an increase in the observed force of about $25 \%$ was recorded for the fully submerged debris compared to the partially submerged debris. In comparison, an increase of about $31 \%$ was recorded for that of the mass of $200 \mathrm{~g}$.

Table 3. Results of Mann-Whitney-Wilcoxon statistical analysis.

\begin{tabular}{cccc}
\hline & R1/1 100 & R1/1 200 & R1/2 100 \\
\hline R1/1 200 & $<2.0 \times 10^{-16}$ & & \\
RP1/2 100 & $<2.0 \times 10^{-16}$ & $<2.0 \times 10^{-16}$ & \\
R1/2 200 & $<2.0 \times 10^{-16}$ & $<2.0 \times 10^{-16}$ & $<2.0 \times 10^{-16}$ \\
\hline
\end{tabular}




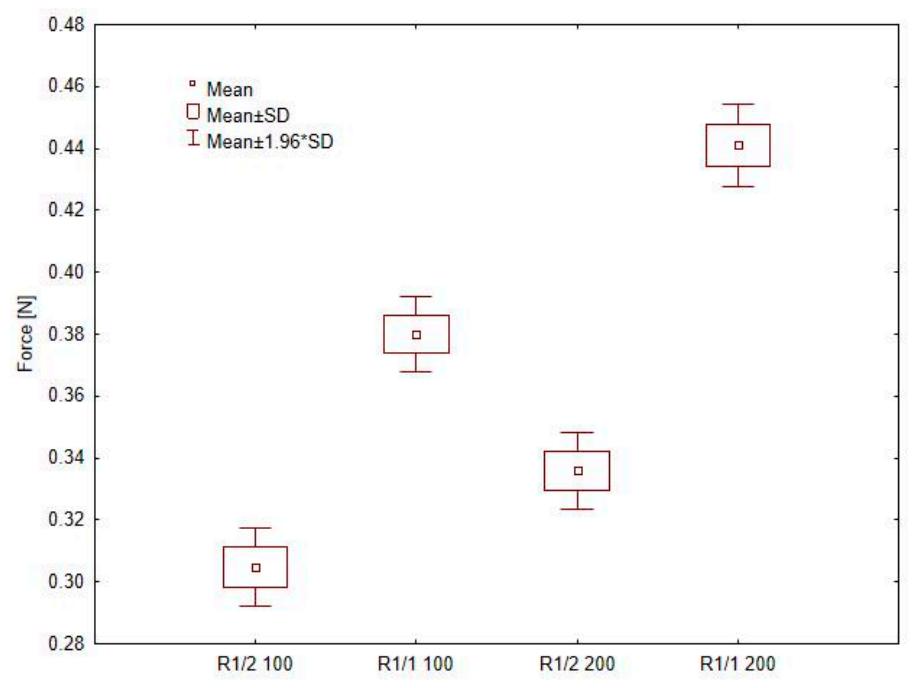

Figure 3. Box plot of summary statistics for conducted measures.

The conducted research using racks arranged at $70^{\circ}$ was similar to [69], where the influence by grids set at different angles and flow values were evaluated. The authors conducted experiments in a hydraulic channel with three designated baffle angles $\left(30^{\circ}\right.$, $60^{\circ}$, and $90^{\circ}$ ) and three flow conditions (high, medium, and low). Tsikata et al. [69] noted a significant reduction in head losses when round leading edges replaced square leading edges of rectangular bars, or if streamlined cross-section profile bars were used instead of rectangular bars.

The installation of racks in the inlet channel of a hydroelectric plant impedes the migration of fish through hydroelectric facilities and may threaten freshwater fish. Such a study was conducted by Szabo-Meszaros et al. [70], who proved from experimental research that the angle of grating placement and its shape has a significant effect on fish viability. Their study used different grating angles and shapes at constant spacing (15 mm) under constant flow conditions.

The phenomenon of flow blockage in an open channel can cause changes in the hydraulics by, among other things, increasing hydraulic losses. This conclusion was reached by Zayed and Farouk [71], whose work was based on experiments conducted under laboratory conditions and explored different flow rates and blockage ratios. The authors conducted measurements in a similar water flow range of $0.020-0.040 \mathrm{~m}^{3} \mathrm{~s}^{-1}$, and they obtained 0.06-0.12 Froud's numbers and from 21,625 to 46,088 Reynold's numbers, which is close to our results, which range from $0.013-0.017$ and 22,061-22,743, respectively. Froude number values obtained during laboratory tests confirm the presence of subcritical flow. For the flows in open channels, the Reynolds number is a linear value [72]. Laminar flow occurs at values less than 500-600. Practically, the transition region is contained in the range 500-2000 [73]. A Reynolds number value $>2000$ indicates turbulent flow. The same trend is noticed in calculated results; the degree of obscuration of the cross-section $B$ presented in Table 2.

A study of the effect of debris accumulation on the grids of hydroelectric facilities and turbines which negatively affected electricity production was conducted by Ibrahimet et al. [74], based on field measurements of the New Naga Hammady Barrages hydropower plant on the Nile River. They noted that the barrages should be designed with a specific location to counteract the transport of debris from high-yield source areas before reaching the hydropower plant.

The proper design of the shape and spacing of the bars of the SHP is the overriding condition for obtaining certain financial effects. There is an ongoing effort to find solutions that are acceptable to architects, engineers, and environmentalists. Therefore, the objective of the study by Josiah et al. [75] was to propose an improved methodology for estimating hydraulic loss in grids installed in hydropower structures by determining 
the blockage factor. Experiments were conducted with a smooth horizontal bottom and partially submerged inlet channels under stable flow conditions.

\section{Conclusions}

Vegetation debris commonly occurs in natural terrain, and its mass, volume, and degree of obscuration of the cross-section affect the loss of channel capacity. The laboratory results obtained from the experiments confirm the influence of the degree of cross-section obscuration on the values of forces.

In our laboratory research conducted in turbulent flow conditions (where Reynolds number was higher than 10,000), we can draw the following conclusions:

- in the case of debris in the form of a rectangle and with a mass of $100 \mathrm{~g}$, it increased by about $25 \%$ concerning the partially submerged one;

- in the case of debris in the form of a rectangle and with a mass of $200 \mathrm{~g}$, it increased by about $31 \%$;

- for half-submerged debris, the increase in force recorded in tensiometer platform was about $15-17 \%$ higher compared to that of clean trash racks (for 100 and $200 \mathrm{~g}$, respectively);

- $\quad$ similarly, for debris fully submergent, the increase in force was about $42-53 \%$ higher than that of clean trash racks.

The conducted research confirmed the impact of accumulated debris and their submerged degree on force value, and consequently, on the proper working of a hydropower plant. We suggest that for future research, not only should the degree of submerged debris and its weight be considered, but also the shape of debris-covered trash racks as well.

Author Contributions: Conceptualisation, N.W.; methodology, N.W., Z.W. and J.N.; validation, N.W., Z.W. and J.N.; formal analysis, N.W., Z.W. and J.N.; writing-original draft preparation, N.W., Z.W. and J.N.; writing-review and editing, N.W., Z.W. and J.N.; visualisation, Z.W. and J.N. All authors have read and agreed to the published version of the manuscript.

Funding: This research received no external funding.

Institutional Review Board Statement: Not applicable.

Informed Consent Statement: Not applicable.

Data Availability Statement: Not applicable.

Conflicts of Interest: The authors declare no conflict of interest.

\section{References}

1. Tomczyk, P.; Wiatkowski, M. Challenges in the Development of Hydropower in Selected European Countries. Water 2020, 12,3542 .

2. Hamududu, B.H.; Killingtveit, Å. Hydropower production in future climate scenarios; the case for the Zambezi River. Energies 2016, 9, 502. [CrossRef]

3. Donk, P.; van Uytven, E.; Willems, P.; Taylor, M.A. Assessment of the potential implications of a $1.5 \mathrm{C}$ versus higher global temperature rise for the Afobaka hydropower scheme in Suriname. Reg. Environ. Chang. 2018, 18, 2283-2295. [CrossRef]

4. Bilotta, G.S.; Burnside, N.G.; Turley, M.D.; Gray, J.C.; Orr, H.G. The effects of run-of-river hydroelectric power schemes on invertebrate community composition in temperate streams and rivers. PLoS ONE 2017, 12, e0171634. [CrossRef] [PubMed]

5. Kjærstad, G.; Arnekleiv, J.V.; Speed, J.D.M.; Herland, A.K. Effects of hydropeaking on benthic invertebrate community composition in two central Norwegian rivers. River Res. Appl. 2018, 34, 218-231. [CrossRef]

6. Zhou, S.; Tang, T.; Wu, N.; Fu, X.; Jiang, W.; Li, F.; Cai, Q. Impacts of cascaded small hydropower plants on microzooplankton in Xiangxi River, China. Acta Ecol. Sin. 2009, 29, 62-68. [CrossRef]

7. Wiatkowski, M.; Rosik-Dulewska, C.; Tomczyk, P. Hydropower structures in the Natura 2000 site on the river Radew: An analysis in the context of sustainable water management. Annu. Set Environ. Prot. 2017, 19, 65-80.

8. Camargo, J.A. Responses of aquatic macrophytes to anthropogenic pressures: Comparison between macrophyte metrics and indices. Environ. Monit. Assess. 2018, 190, 1-11. [CrossRef]

9. Vowles, A.S.; Karlsson, S.P.; Uzunova, E.P.; Kemp, P.S. The importance of behaviour in predicting the impact of a novel small-scale hydropower device on the survival of downstream moving fish. Ecol. Eng. 2014, 69, 151-159. [CrossRef] 
10. Chiogna, G.; Majone, B.; Paoli, K.C.; Diamantini, E.; Stella, E.; Mallucci, S.; Lencioni, V.; Zandonai, F.; Bellin, A. A review of hydrological and chemical stressors in the Adige catchment and its ecological status. Sci. Total Environ. 2016, 540, 429-443. [CrossRef]

11. Bejarano, M.D.; Sordo-Ward, Á.; Alonso, C.; Nilsson, C. Characterizing effects of hydropower plants on sub-daily flow regimes. J. Hydrol. 2017, 550, 186-200. [CrossRef]

12. Młyński, D.; Operacz, A.; Wałega, A. Sensitivity of methods for calculating environmental flows based on hydrological characteristics of watercourses regarding the hydropower potential of rivers. J. Clean. Prod. 2020, 250, 119527. [CrossRef]

13. Nguyen, T.H.T.; Forio, M.A.E.; Boets, P.; Lock, K.; Damanik Ambarita, M.N.; Suhareva, N.; Everaert, G.; Dominguez-Granda, L.E.; Hoang, T.H.T.; Goethals, P. Threshold responses of macroinvertebrate communities to stream velocity in relation to hydropower dam: A case study from the Guayas river basin (Ecuador). Water 2018, 10, 1195. [CrossRef]

14. Bogen, J.; Bønsnes, T.E. The impact of a hydroelectric power plant on the sediment load in downstream water bodies, Svartisen, northern Norway. Sci. Total Environ. 2001, 266, 273-280. [CrossRef]

15. Kumar, A.; Sharma, M.P. Greenhouse gas emissions from hydropower reservoirs. Hydro Nepal J. Water Energy Environ. 2012, 11, 37-42. [CrossRef]

16. Soininen, N.; Belinskij, A.; Vainikka, A.; Huuskonen, H. Bringing back ecological flows: Migratory fish, hydropower and legal maladaptivity in the governance of Finnish rivers. Water Int. 2019, 44, 321-336. [CrossRef]

17. Klaver, G.; van Os, B.; Negrel, P.; Petelet-Giraud, E. Influence of hydropower dams on the composition of the suspended and riverbank sediments in the Danube. Environ. Pollut. 2007, 148, 718-728. [CrossRef]

18. Del Tánago, M.G.; Gurnell, A.M.; Belletti, B.; Jalón, D.G. Indicators of river system hydromorphological character and dynamics: Understanding current conditions and guiding sustainable river management. Aquat. Sci. 2016, 78, 35-55. [CrossRef]

19. Anderson, D.; Moggridge, H.; Warren, P.; Shucksmith, J. The impacts of "run-of-river' hydropower on the physical and ecological condition of rivers. Water Environ. J. 2015, 29, 268-276. [CrossRef]

20. Kougias, I.; Aggidis, G.; Avellan, F.; Deniz, S.; Lundin, U.; Moro, A.; Muntean, S.; Novara, D.; Pérez-Díaz, J.I.; Quaranta, E. Analysis of emerging technologies in the hydropower sector. Renew. Sustain. Energy Rev. 2019, 113, 109257. [CrossRef]

21. Bishwakarma, M.B.; Støle, H. Real-time sediment monitoring in hydropower plants. J. Hydraul. Res. 2008, 46, 282-288. [CrossRef]

22. Wiatkowski, M.; Tomczyk, P. Comparative Assessment of the Hydromorphological Status of the Rivers Odra, Bystrzyca, and Ślęza using the RHS, LAWA, QBR, and HEM Methods above and below the Hydropower Plants. Water 2018, 10, 855. [CrossRef]

23. Bakken, T.H.; Sundt, H.; Ruud, A.; Harby, A. Development of small versus large hydropower in Norway-Comparison of environmental impacts. Energy Procedia 2012, 20, 185-199. [CrossRef]

24. Bunea, F.; Ciocan, G.D.; Oprina, G.; Băran, G.; Băbuţanu, C.A. Hydropower impact on water quality. Environ. Eng. Manag. J. 2010, 9, 1459-1464. [CrossRef]

25. Siergieiev, D.; Widerlund, A.; Lundberg, A.; Almqvist, L.; Collomp, M.; Ingri, J.; Öhlander, B. Impact of hydropower regulation on river water composition in Northern Sweden. Aquat. Geochem. 2014, 20, 59-80. [CrossRef]

26. Tomczyk, P.; Wiatkowski, M. Shaping changes in the ecological status of watercourses within barrages with hydropower schemes-literature review. Arch. Environ. Prot. 2020, 46, 78-94.

27. Kelly-Richards, S.; Silber-Coats, N.; Crootof, A.; Tecklin, D.; Bauer, C. Governing the transition to renewable energy: A review of impacts and policy issues in the small hydropower boom. Energy Policy 2017, 101, 251-264. [CrossRef]

28. Rodriguez, J.-F. Hydropower landscapes and tourism development in the Pyrenees. From natural resource to cultural heritage. J. Alp. Res. Rev. Géographie Alp. 2012. [CrossRef]

29. Ezcurra, E.; Barrios, E.; Ezcurra, P.; Ezcurra, A.; Vanderplank, S.; Vidal, O.; Villanueva-Almanza, L.; Aburto-Oropeza, O. A natural experiment reveals the impact of hydroelectric dams on the estuaries of tropical rivers. Sci. Adv. 2019, 5, eaau9875. [CrossRef] [PubMed]

30. Spänhoff, B. Current status and future prospects of hydropower in Saxony (Germany) compared to trends in Germany, the European Union and the World. Renew. Sustain. Energy Rev. 2014, 30, 518-525. [CrossRef]

31. Igliński, B. Hydro energy in Poland: The history, current state, potential, SWOT analysis, environmental aspects. Int. J. Energy Water Resour. 2019, 3, 61-72. [CrossRef]

32. Wei, G.; Yang, Z.; Cui, B.; Li, B.; Chen, H.; Bai, J.; Dong, S. Impact of dam construction on water quality and water self-purification capacity of the Lancang River, China. Water Resour. Manag. 2009, 23, 1763-1780. [CrossRef]

33. Bildirici, M.E.; Gökmenoğlu, S.M. Environmental pollution, hydropower energy consumption and economic growth: Evidence from G7 countries. Renew. Sustain. Energy Rev. 2017, 75, 68-85. [CrossRef]

34. De Almeida, A.T.; Moura, P.S.; Marques, A.S.; Almeida, J.L. Multi-impact evaluation of new medium and large hydropower plants in Portugal centre region. Renew. Sustain. Energy Rev. 2005, 9, 149-167. [CrossRef]

35. Botelho, A.; Ferreira, P.; Lima, F.; Pinto, L.M.C.; Sousa, S. Assessment of the environmental impacts associated with hydropower. Renew. Sustain. Energy Rev. 2017, 70, 896-904. [CrossRef]

36. Valero, E. Characterization of the water quality status on a stretch of River Lérez around a small hydroelectric power station. Water 2012, 4, 815-834. [CrossRef]

37. Santos, J.M.; Ferreira, M.T.; Pinheiro, A.N.; Bochechas, J.H. Effects of small hydropower plants on fish assemblages in mediumsized streams in central and northern Portugal. Aquat. Conserv. Mar. Freshw. Ecosyst. 2006, 16, 373-388. [CrossRef] 
38. Jesus, T.; Formigo, N.; Santos, P.; Tavares, G.R. Impact evaluation of the Vila Viçosa small hydroelectric power plant (Portugal) on the water quality and on the dynamics of the benthic macroinvertebrate communities of the Ardena river. Limnetica 2004, 23, 241-255.

39. Xiaocheng, F.; Tao, T.; Wanxiang, J.; Fengqing, L.; Naicheng, W.; Shuchan, Z.; Qinghua, C. Impacts of small hydropower plants on macroinvertebrate communities. Acta Ecol. Sin. 2008, 28, 45-52. [CrossRef]

40. Larinier, M. Fish passage experience at small-scale hydro-electric power plants in France. Hydrobiologia 2008, 609, 97-108. [CrossRef]

41. Balkham, M.; Fosbeary, C.; Kitchen, A.; Rickard, C. Culvert Design and Operation Guide; Construction and Industry Research and Information Association: London, UK, 2010.

42. Walczak, N.; Walczak, Z.; Nieć, J. Assessment of the Resistance Value of Trash Racks at a Small Hydropower Plant Operating at Low Temperature. Energies 2020, 13, 1775. [CrossRef]

43. Gebre, S.; Alfredsen, K.; Lia, L.; Stickler, M.; Tesaker, E. Review of ice effects on hydropower systems. J. Cold Reg. Eng. 2013, 27, 196-222. [CrossRef]

44. Jenssen, L.; Tesaker, E.; Lund, S.; Huber, D. Inntakshåndboken-Rettledning og Utforming av Inntak til Små Kraftverk i Norge. NVE's Hustrykkeri; Norges Vassdrags-og Energidirektorat: Oslo, Norway, 2006; ISSN 1501-0678.

45. Blanc, J.; Wallerstein, N.P.; Arthur, S.; Wright, G.B. Analysis of the performance of debris screens at culverts. In Proceedings of the Institution of Civil Engineers-Water Management; Thomas Telford Ltd: London, UK, 2014; pp. 219-229. ISBN 17417589.

46. Jaeger, R.; Lucke, T. Investigating the relationship between rainfall intensity, catchment vegetation and debris mobility. International J. Geomate 2017, 12, 22-29. [CrossRef]

47. Wang, S.; Meng, X.; Chen, G.; Guo, P.; Xiong, M.; Zeng, R. Effects of vegetation on debris flow mitigation: A case study from Gansu province, China. Geomorphology 2017, 282, 64-73. [CrossRef]

48. Michelini, T.; Bettella, F.; D'Agostino, V. Field investigations of the interaction between debris flows and forest vegetation in two Alpine fans. Geomorphology 2017, 279, 150-164. [CrossRef]

49. Shen, P.; Zhang, L.M.; Chen, H.X.; Gao, L. Role of vegetation restoration in mitigating hillslope erosion and debris flows. Eng. Geol. 2017, 216, 122-133. [CrossRef]

50. Gasser, E.; Simon, A.; Perona, P.; Dorren, L.; Hübl, J.; Schwarz, M. Quantification of potential recruitment of large woody debris in mountain catchments considering the effects of vegetation on hydraulic and geotechnical bank erosion and shallow landslides. In Proceedings of the E3S Web of Conferences 40, Lyon-Villeurbanne, France, 5-8 September 2018; EDP Sciences: Les Ulis, France, 2018; p. 2046, ISBN 2267-1242.

51. Walczak, N. Operational evaluation of a small hydropower Plant in the Context of sustainable development. Water 2018, 10, 1114. [CrossRef]

52. Chang, F.F.M.; Shen, H.W. Debris Problems in the River Environment; Rep. No. FHWA-RD-79-62; FederalHighway Administration: Washington, DC, USA, 1979.

53. Diehl, T.H. Potential Drift Accumulation at Bridges; US Department of Transportation, Federal Highway Administration, Research: Washington, DC, USA, 1997.

54. Bradley, J.B.; Richards, D.L.; Bahner, C.D. Debris Control Structures-Evaluation and Countermeasures; Hydraulic Engineering Circular U.S. Department of Transportation: Washington, DC, USA, 2005.

55. Stockstill, R.L.; Daly, S.F.; Hopkins, M.A. Modeling floating objects at river structures. J. Hydraul. Eng. 2009, 135, 403-414. [CrossRef]

56. Schmocker, L.; Hager, W.H. Scale modeling of wooden debris accumulation at a debris rack. J. Hydraul. Eng. 2013, 139, 827-836. [CrossRef]

57. Schalko, I.; Schmocker, L.; Weitbrecht, V.; Boes, R.M. Backwater rise due to large wood accumulations. J. Hydraul. Eng. 2018, 144, 4018056. [CrossRef]

58. Liébault, F.; Piégay, H. Causes of 20th century channel narrowing in mountain and piedmont rivers of southeastern France. Earth Surface Processes and Landforms. J. Br. Geomorphol. Res. Group 2002, 27, 425-444.

59. Kondolf, G.M.; Piégay, H.; Landon, N. Changes in the riparian zone of the lower Eygues River, France, since 1830. Landsc. Ecol. 2007, 22, 367-384. [CrossRef]

60. Jeżowiecka-Kabsch, K.; Szewczyk, H. Mechanika Płynów; Oficyna Wydawnicza Politechniki Wrocławskiej: Wroclaw, Poland, 2001; ISBN 8370855911.

61. Verzani, J. Using $R$ for Introductory Statistics, 2nd ed.; CRC Press: Boca Raton, FL, USA, 2015; ISBN 9781466590731.

62. Hollander, M.; Wolfe, D.A.; Chicken, E. Nonparametric Statistical Methods, 3rd ed.; Wiley: Hoboken, NJ, USA, 2014; ISBN 0470387378.

63. Xiang, F.; Kavvas, L.M.; Chen, Z.; Bandeh, H.; Ohara, N.; Kim, S.; Jang, S.-H.; Churchwell, R. Experimental study of debris capture efficiency of trash racks. J. Hydro-Environ. Res. 2009, 3, 138-147. [CrossRef]

64. Lučin, I.; Čarija, Z.; Grbčić, L.; Kranjčević, L. Assessment of head loss coefficients for water turbine intake trash-racks by numerical modeling. J. Adv. Res. 2020, 21, 109-119. [CrossRef]

65. Wallerstein, N.P.; Alonso, C.V.; Bennett, S.J.; Thorne, C.R. Distorted Froude-scaled flume analysis of large woody debris. Earth Surf. Process. Landf J. Br. Geomorphol. Res. Group 2001, 26, 1265-1283. [CrossRef] 
66. Hygelund, B.; Manga, M. Field measurements of drag coefficients for model large woody debris. Geomorphology 2003, 51, 175-185. [CrossRef]

67. Clark, S.P.; Tsikata, J.M.; Haresign, M. Experimental study of energy loss through submerged trashracks. J. Hydraul. Res. 2010, 48, 113-118. [CrossRef]

68. Gippel, C.J.; O’Neill, I.C.N.; Finlayson, B.L.; Schnatz, I. Hydraulic guidelines for the re-introduction and management of large woody debris in lowland rivers. Regul. Rivers Res. Manag. 1996, 12, 223-236. [CrossRef]

69. Tsikata, J.M.; Tachie, M.F.; Katopodis, C. Open-channel turbulent flow through bar racks. J. Hydraul. Res. 2014, 52, 630-643. [CrossRef]

70. Szabo-Meszaros, M.; Navaratnam, C.U.; Aberle, J.; Silva, A.T.; Forseth, T.; Calles, O.; Fjeldstad, H.-P.; Alfredsen, K. Experimental hydraulics on fish-friendly trash-racks: An ecological approach. Ecol. Eng. 2018, 113, 11-20. [CrossRef]

71. Zayed, M.; Farouk, E. Effect of blocked trash rack on open channel infrastructure. Water Pract. Technol. 2021, 16, 247-262. [CrossRef]

72. Lewandowski, J.B. Fluid Mechanics; Wydawnictwo Akademii Rolniczej im. Augusta Cieszkowskiego: Poznan, Poland, 2006; ISBN 9788371604089. (In Polish)

73. Chow, V.T. Open-Channel Hydraulics; McGraw-Hill: New York, NY, USA, 1959.

74. Ibrahim, H.; Osman, E.A.; El-Samman, T.A.; Zayed, M. Aquatic Weed Management Upstream New Naga Hammady Barrages; Eighteenth International Water Technology Conference; IWTC18: Sharm El-Sheikh, Egypt, 2015.

75. Josiah, N.R.; Pathirana, K.P.; Tissera, H.P. An Experimental Investigation of Head Loss Through Trash Racks in Conveyance Systems. J. Inst. Eng. Sri Lanka 2016, 49, 1-8. [CrossRef] 